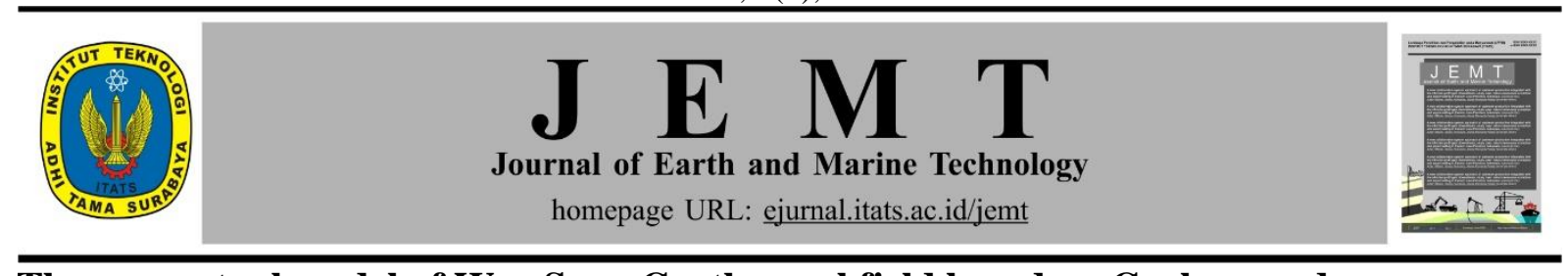

The conceptual model of Wae Sano Geothermal field based on Geology and

\title{
Geochemistry data
}

Fajar Rizki Widiatmoko ${ }^{1}$, Mochammad Nur Hadi ${ }^{2}$, Dedi Kusnadi ${ }^{2}$, Sachrul Iswahyudi ${ }^{3}$, Fadlin ${ }^{3}$

${ }^{1}$ Faculty of Mineral and Marine Technology, Institut Teknologi Adhi Tama Surabaya

${ }^{2}$ Pusat Sumber Daya Mineral Batubara dan Panas Bumi, Badan Geologi - ESDM

${ }^{3}$ Department of Geological Engineering, University of Jenderal Soedirman

e-mail: widiatmoko@itats.ac.id

DOI: $10.31284 /$ j.jemt.2020.v1i1.1189

\section{Article info}

Received:

27 June 2020

Revised:

27 August 2020

Accepted:

30 August 2020

Published:

30 September 2020

\section{Keywords:}

Sano Nggoang,

Manggarai Barat

Regency, reservoir

characterization

\begin{abstract}
Wae Sano volcano is included in the inner Banda arc, Mount Wae Sano is a type $\mathrm{C}$ volcano and formed the Sano Nggoang crater lake. The magmatism activity produces geothermal manifestations such as; hot spring, rock alteration, and sulfur deposits, the hottest water temperature is $81{ }^{\circ} \mathrm{C}$, with neutral $\mathrm{pH}$, but the Sano Nggoang Lake water has acid $\mathrm{pH}$. It becomes interesting to examine the characteristics of the geothermal system in that area. The research was conducted by Volcanostratigraphic studies to reconstruct the geological process and Geochemical sampling of hot springs, lake water, ground air, and the soil side to understand the subsurface characterization. The result showing some period of volcano products, with the youngest come from the product of Sano Nggoang 2 that spills its product to on the north-east side of Poco Dedeng volcano. The geochemical analysis shows all manifestations originate from one reservoir, chloride water type, $\mathrm{NaCl}$ type of the lake water with a few $\mathrm{SO}_{4}$ influence, presumably, the hot springs supply is influenced by seawater, the estimation of the reservoir has a temperature about $\pm 230{ }^{\circ} \mathrm{C}$, with dacite and the rich organic sedimentary rock, and located at $\pm 1456 \mathrm{~m}$ from the manifestation, the isothermal section shows the rate of temperature increase at $97.07 \mathrm{~m} / 10{ }^{\circ} \mathrm{C}$. The hypothetical resource is counted about $1,488.6 \mathrm{kWe}$.
\end{abstract}

\section{Introduction}

The research location is in the Wae Sano area, Sano Nggoang District, West Manggarai Regency, East Nusa Tenggara Province. The research area is on the Banda arc volcanic route [1], [2], where the volcano is included in the type $\mathrm{C}$ volcano [3]. In this area, there is a case that lake water has an acidic $\mathrm{pH}$, with very high electro-conductivity properties, while the $\mathrm{pH}$ of hot springs that are the source of lake irrigation is neutral $\mathrm{pH}$. It is interesting to research geology to determine the distribution of rocks to geological and geochemical conditions to determine the characteristics of the geothermal system in the research area.

\section{Methodology}

The methodology of this research uses a wide scope to the specific scope of the study. The remote sensing is used to aim the interest area, the geological mapping is conducted to know rock distribution, the geochemical sampling is conducted to know characterization of the subsurface condition according to the chemistry analysis, and the soil sampling is conducted to find the chemical interest distribution.

Interpretation of the available image data is the GDEM2ASTER image, where the image is drawn which is estimated as a fracture and straightness, the lines must be the same length. The results of this image interpretation will produce a straight line map and a fault fracture density (FFD) map [4]. Geological mapping activities include geomorphological observations, collecting surface rock data, petrographic observations, making stratigraphic columns, determining age through dating methods, making 
geological reconstruction sections, and reconstructing the geological history of the research area [5], [6]. Geochemical data collection activities include hot water sampling, cold water sampling, hot water temperature measurement, $\mathrm{pH}$ measurement for each water sample, manifestation water discharge measurement, and measuring the electro-conductivity of each water sample. Cation water samples were measured by an automatic atom spectrophotometer (AAS), while anion samples were measured by ion chromatography. The measurement results of the samples were analyzed using the $\mathrm{Cl}-\mathrm{SO}_{4}-\mathrm{HCO}_{3}$ diagram, the Na-K-Mg diagram [7], the Cl-Li-B diagram, the elemental geo-indicator, and the element ratio [8], [9], [10]. Soil geochemical data collection includes soil sampling and soil $\mathrm{CO}_{2}$, where the sampling distance is $\pm 1 \mathrm{~km}$ from other soil sampling points, sampling is carried out on soil horizon B, or it is assumed to be $\pm 1 \mathrm{~m}$ deep. Soil samples were measured with a mercury analyzer to determine mercury levels, soil $\mathrm{CO}_{2}$ samples were measured using the titration method to determine soil $\mathrm{CO}_{2}$ levels $[10]$.

\section{Results and discussion}

\subsection{The remote sensing analysis}

Based on the results of the GDEM2ASTER image interpretation (Figure 1, left), the results of the $\mathrm{N} 3150 \mathrm{E}$ dominant straight line pattern are the dominant fracture patterns that are formed in the area. It is assumed that the direction of the force that causes the fracture, apart from originating from inside the volcano, also possibly originates from NW-SE, while the extensional force is in the direction of NESW. The fracture intensity analysis (FFD) (Figure 2, right) shows that areas that have many fractures are in the West, East, and Northeast of Wae Sano Lake. This is evidenced by the emergence of hot springs (East of the lake), sintered silica (East of the lake), and altered rocks (all fractured areas are large). The estimation from the FFD data is interpreted as a trace of hydrothermal activity, where the hydrothermal fluid will pass through the existing fractures.

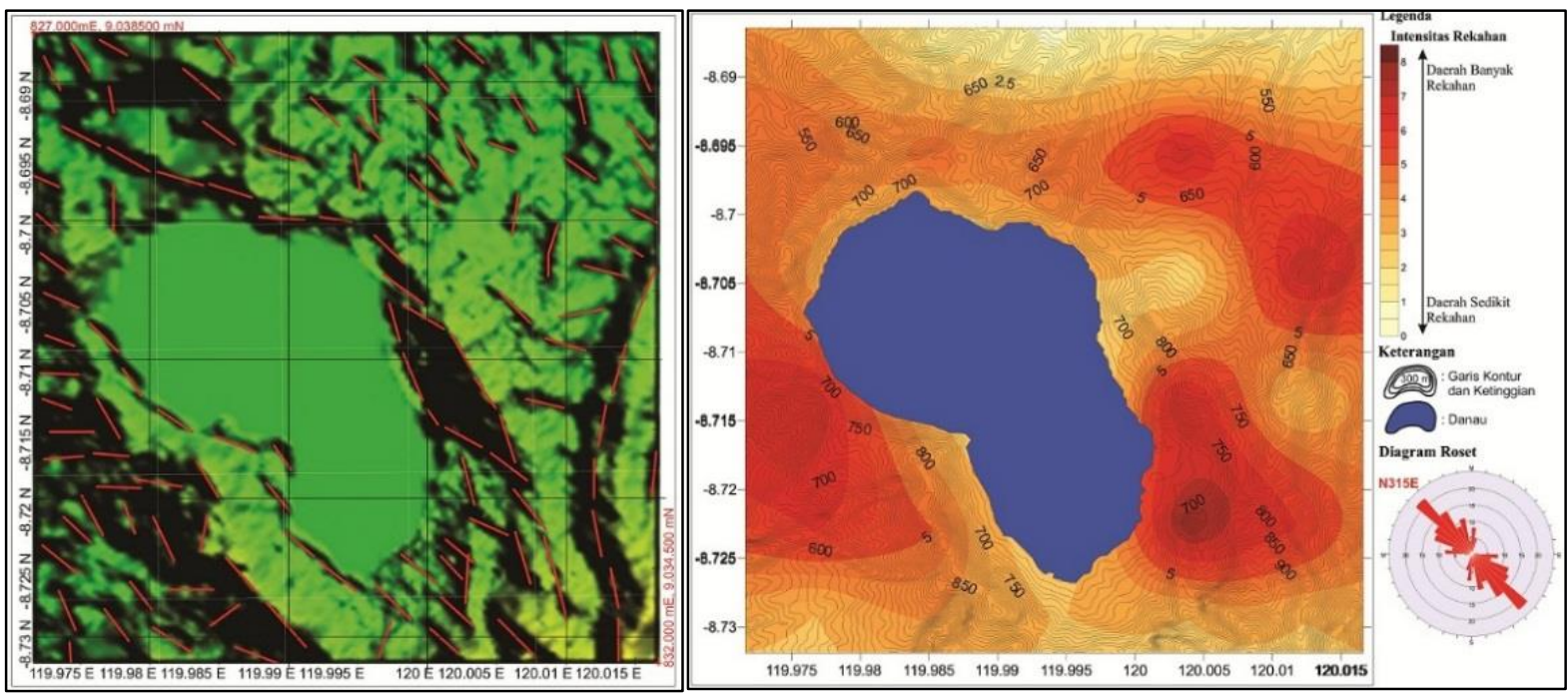

Figure 1. The distribution of the lineaments (left), the FFD map (right)

\subsection{Geological map}

The results of geological mapping show that geomorphologically, the research area is divided into 3 volcanic cones [11], namely the Poco Dedeng Volcanic Cone in the Southeast, the Sano Nggoang Volcano Cone in the Middle, where the Sano Nggoang volcanic cone has caldera walls that make up the ridge. Wae Sano Lake barrier, and Mbeliling Volcano Cone in the Northwest. Geologically, the Sano Nggoang volcano is a Plinian volcanic explosion type where the position of the magma chamber tends to be shallow and a bit thick, resulting in a large explosion and the formation of a caldera. Lake Wae Sano is a caldera as a trace of a volcanic explosion, where the caldera is formed by deflationary forces (shrinkage) caused by the belly of the volcano losing its style [6]. Judging from the lake pattern, if the reconstruction is carried out there are two circles that converge, so it is assumed that the volcano has experienced two volcanic eruption holes forming. The exposed rocks are divided into 5, namely; the Poco Dedeng Lava Unit in the Southeast, the Sano Nggoang 1 Lava Unit which points to the Northwest, 
the Sano Nggoang 1 Pyroclastic Breccia Unit which points to the West, the Sano Lava Unit Nggoang 2 to the east, and the Sano Nggoang 2 Pyroclastic Breccia Unit to the northeast (Picture 2). Furthermore, the correlation of rock units was carried out, to determine their relative and absolute age, based on the dating results, it was found that the age of the Poco Dedeng Lava Unit was at the age of $0.3 \mathrm{Ma}$ [12] equivalent to the Pleistocene, and the Sano Nggoang 1 Lava Unit was at the age of $0.2 \mathrm{Ma}$ [12]or equivalent to the Pleistocene. Then performed a geological cross-section reconstruction to determine the geological history (Figure 2). In terms of petrographic, lava products, and pyroclastic coverage that tends to be monomic, the results of the same petrographic analysis are obtained, namely Dacite [13]. This is a support that the Wae Sano volcano is a Pilinian explosion type volcano with magma that tends to be thick.

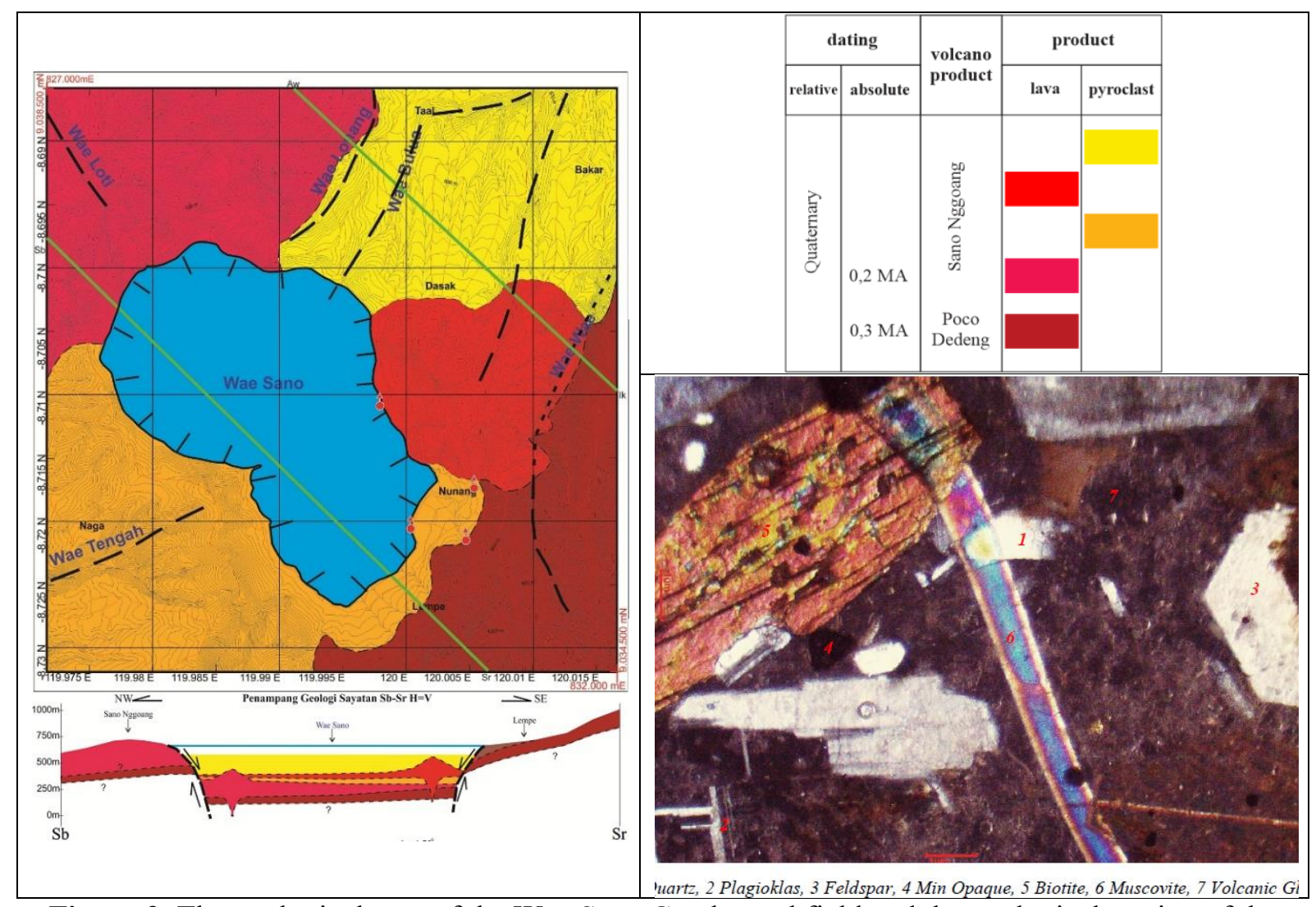

Figure 2. The geological map of the Wae Sano Geothermal field and the geological section of the study area (left), the rock dating of the study area (top right), and the petrographic analysis

The end of the geological mapping section is making the geological history of the research area, where at the Miocene age is the process of forming sedimentary rocks in shallow marine environments as bedrock [12]. Then at the Pliocene-Pleistocene age, the seabed was lifted as a result of the collision of the Eurasian plate with the Indies-Australia [2], [14], the uplifted seabed become island is forming changes of sediment quality [15]. Subsequently, the Poco Dedeng volcano was formed as a result of the subduction between the Eurasia and Indies-Australia plates and ended at the age of 0.3Ma. Then the eruption of the Sano Nggoang 1 volcano product on the northwest slope of the Poco Dedeng volcano at the age of 0.2Ma. Lastly, Sano Nggoang 2 volcano product was released on the northern slope of Poco Dedeng volcano. After releasing volcanic products in the form of pyroclastic deposits, the volcano's stomach loses pressure which causes deflation (shrinkage) of the volcano's body or collapses, so that the Sano Nggoang caldera is formed (Figure 3). 


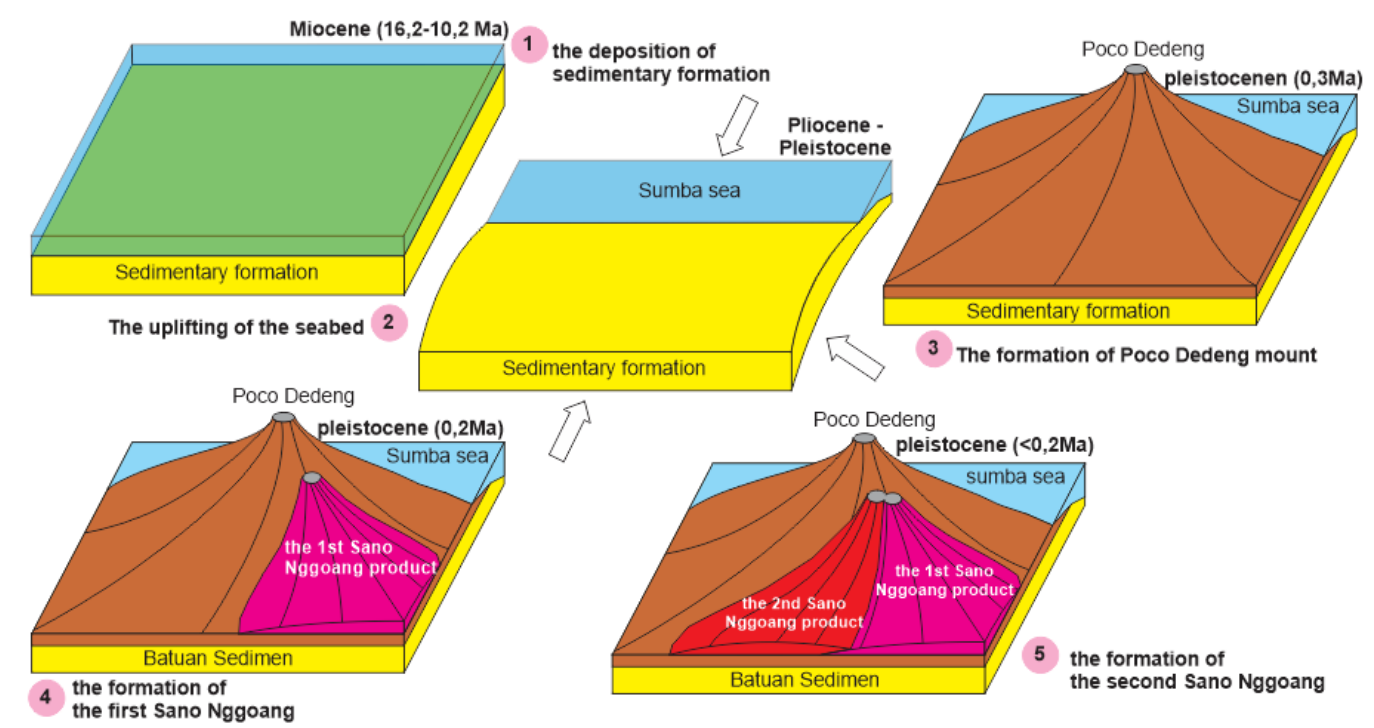

Figure 3. Reconstruction of Geological History

\subsection{The water geochemistry}

Based on field data, it was found 4 hot springs with a distance of each spring that is close together $(100 \mathrm{~m}-500 \mathrm{~m})$. Then hot water sampling, and taking 3 cold water samples in the southern part of the lake, northwest of the lake, and northeast of the lake (lake water drainage). Based on the results of the plotting on the ternary diagram $\mathrm{Cl}-\mathrm{SO}_{4}-\mathrm{HCO}_{3}$ (Figure 4, left) [10], [16], the results show that the APWS1 and APWS2 samples are $\mathrm{Cl}$ water which is deep reservoir water [17], while the APWS4 sample is $\mathrm{SO} 4$ water which is volcanic water [18].
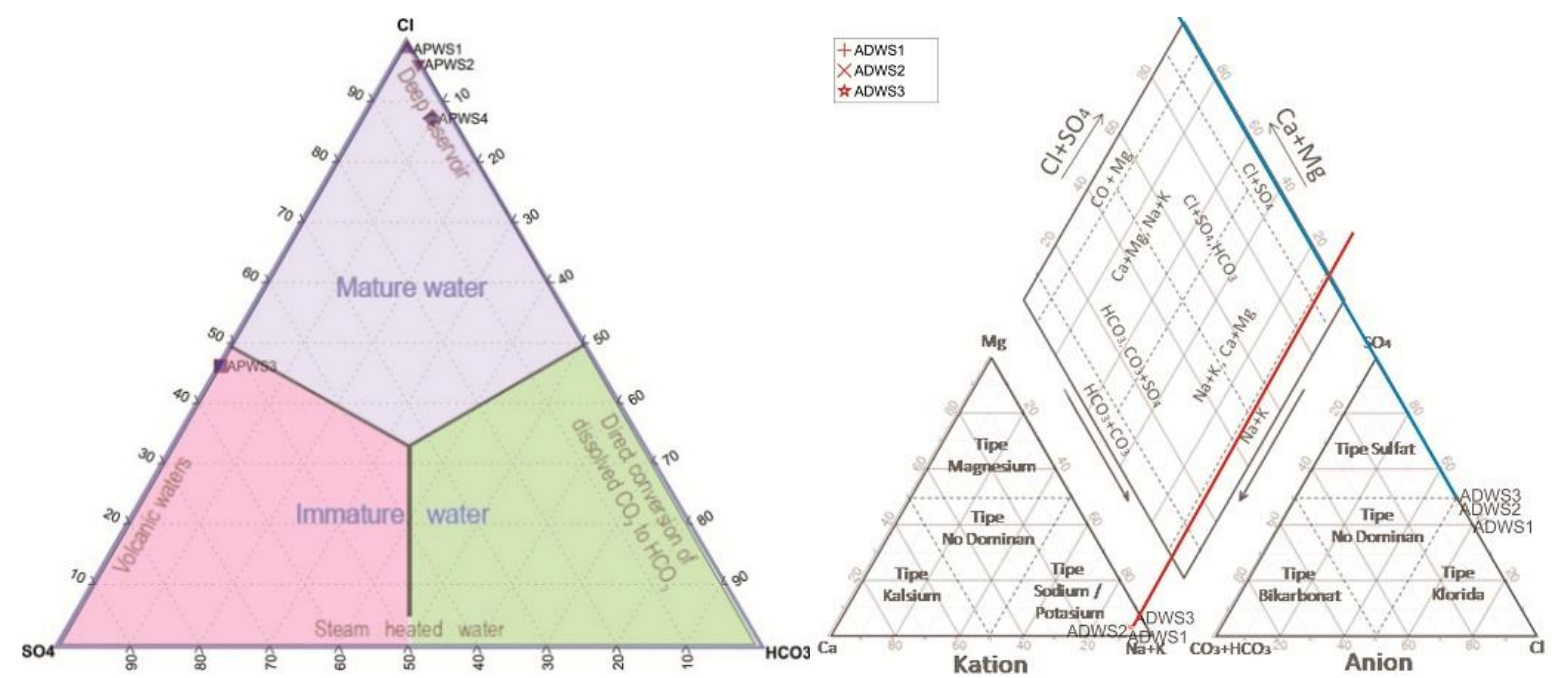

Figure 4. The trinary plot of the hot water type (left), the plot of the cold water type (right).

The type of chloride hot water in this area is of course also influenced by leaching and the interaction with sedimentary rock as the base rock, this assumption is supported by the value of electrical conductivity and the content of the $\mathrm{Cl}$ composition which is higher than deepwater reservoirs in general. This condition will greatly affect the geothermometer calculation of the reservoir in the geothermal system in Wae Sano. $\mathrm{SO}_{4}$ is water that comes from the volcanic activity where the water is strongly influenced by volcanic gases so that it is very acidic. The APWS4 sample is thought to have originated from a deep reservoir but there was mixing with volcanic gases so that the APWS4 sample entered the $\mathrm{SO}_{4}$ water type. The very acidic $\mathrm{pH}$ composition of lake water is the result of steam-heated, which is captured by the $\mathrm{H}_{2} \mathrm{O}$ element, causing a lake with a diameter of $3 \mathrm{~km}$ and $30 \mathrm{~m}$ deep to become acidic and around it will appear sulfur deposits. 
Based on the analysis of the trilinear anion and cation diagrams, the cold water sample in the lake is a type of $\mathrm{NaCl}$ water [18], also known as saltwater. The appearance of this saltwater is closely related to seawater, the water of one lake is $\mathrm{NaCl}$ water with little $\mathrm{SO}_{4}$ influence, the water source comes from a reservoir that is affected by seawater, or there is also a possibility that formation water will then be drained to the surface by heat when the water is collected (Figure 4, right). in the lake, the water is mixed with volcanic gases. The brine intrusion model diagram helps explain this phenomenon, which, when combined with geological data, shows the intrusion of saltwater from the sea, moreover there is the influence of heat causing the water to rise to Sano Nggoang lake (Figure 5).

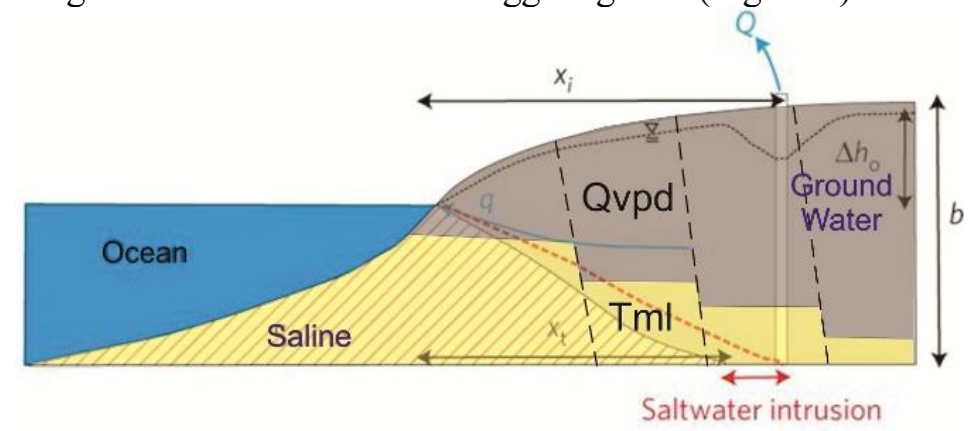

Figure 5. The reconstruction model (adapted from [19]) to explain how seawater is heated and rise to the Sano Nggoang lake.

Based on the results of the $\mathrm{Na} / 1000-\mathrm{K} / 100-\sqrt{\mathrm{Mg}}$ trilinear diagram analysis (Figure 6 , left), it shows that the APWS1 and APWS2 samples are partial equilibrium water [7] or water that has been in equilibrium with the reservoir rock, so the chemical content characteristics of the sample represent the characteristics of the reservoir rock. Then for the APWS4 sample, it is a sample of immature water [10] or water that is no longer balanced because the water has been mixed with other water, so it does not reflect the characteristics of the water's origin. Geothermometer calculations show that the APWS1 and APWS2 samples are at a reservoir temperature of $\pm 230{ }^{\circ} \mathrm{C}$ [7]. Based on the temperature, it is included in high enthalpy resources [10].

The results of the $\mathrm{Cl} /$ 100-Li-B / 4 analysis showed that the APWS1 and APWS2 samples were derived from side rocks between Rhyolite - Basalt [17], this is synchronous with the geological identification results, the name side rocks tend to be Dacitic.

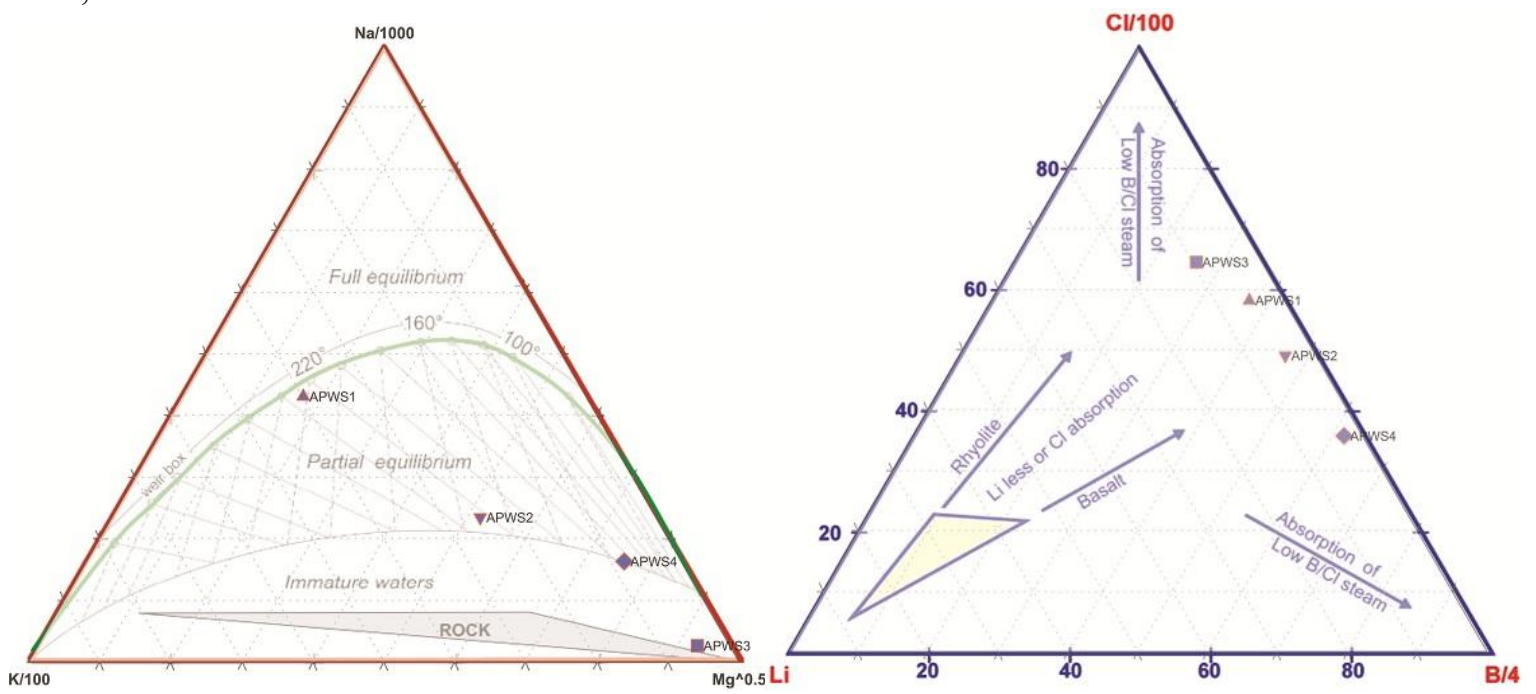

Figure 6. The trinary plot to know the geoindicator and geothermometer (adapted from [7], [10]) (left). The trinary diagram to know the rock type of the reservoir (adapted from [10]) (right).

Geoindicator analysis shows, Boron with a high enough value, so there is a possibility of the influence of sedimentary rocks, the sea sediment conditions enrich the $\mathrm{Cl}$ element in the hot fluid so that the value is very high. APWS3 and APWS4 are samples that have occurred mixing with meteoric water, seen from very low APWS3 is water with poor ion balance (-16.99\%), also low APWS4 samples show 
immature water. The HCO3 / SO4 ratio to determine the flow or outflow zone, APWS1, APWS2, APWS3, and APWS4 are upflow zones, fluids are affected by seawater, and in the same reservoir.
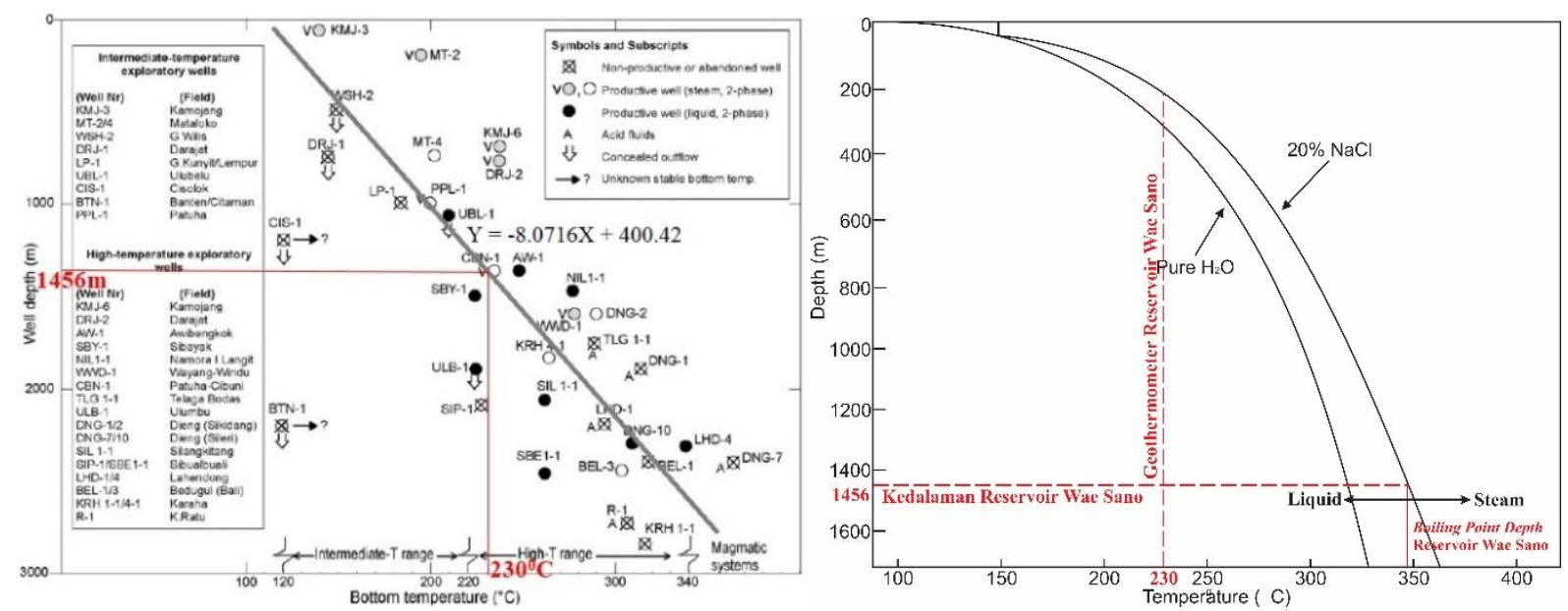

Figure 7. the diagram to know the reservoir depth (adapted from [20]) (left), the diagram to know the fluid phase in the reservoir (adapted from [21]) (right).

The results of the analysis of geothermal calculations at $230{ }^{\circ} \mathrm{C}$ are then entered into the temperature equation against the depth of the temperature gradient equation for the depths of all geothermal fields in Indonesia [20]. Based on the estimation diagram into the reservoir, the estimation results of the reservoir depth are at $\pm 1456 \mathrm{~m}$ below the manifestation (Figure 7, left).

The results of the reservoir depth estimation are then analyzed using the boiling point depth diagram. Where this diagram serves to determine the boiling point of water at a certain depth and pressure, because naturally the higher the environmental pressure, it will require a higher temperature to boil a solution. The diagram shows, for a depth of $\pm 1456 \mathrm{~m}$, a temperature of $\pm 345^{\circ} \mathrm{C}$ is needed to boil $\mathrm{NaCl}$ water. So it can be concluded that the phase system in the reservoir is in the liquid phase. The reservoir in the liquid phase is quite supportive as the reason why lake water is the $\mathrm{NaCl}$ type. Theoretically, when seawater evaporates, $\mathrm{H}_{2} \mathrm{O}$ will evaporate while $\mathrm{NaCl}$ will remain in the sea. Because of this theory, the reservoir system has a liquid phase (does not evaporate) (Figure 7right) when the water is lifted causing $\mathrm{NaCl}$ to be carried up to the surface so that the lake water at an elevation of \pm 650 meters above sea level tends to be of the $\mathrm{NaCl}$ type.

\subsection{The soil geochemistry}

A sampling of soil and soil $\mathrm{CO}_{2}$ each of 28 samples. The sampling locations were spread out with a distance of $\pm 1 \mathrm{~km}$ from each sampling location. Then the samples were analyzed in the laboratory to determine the soil $\mathrm{Hg}$ content and the percentage of soil $\mathrm{CO}_{2} . \mathrm{CO}_{2}$ is a gas that indicates a gas from combustion so that it is an indication that the underground is heating up, then the soil $\mathrm{CO}_{2}$ gas will be trapped in the soil pores. $\mathrm{Hg}$ is one of the metal elements that is easily evaporated, so it is estimated that from underground if there is heat activity it can result in the evaporation of $\mathrm{Hg}$ so that $\mathrm{Hg}$ will be trapped in the pores of the soil layer.

On the Hg distribution map (Figure 8 left), it was found that the two areas had quite high levels of $\mathrm{Hg}$. Southeast area map and East lake area. This is an assumption that the area has experienced heating from underground, supported also when altered rocks are found in the area, as an indication that alteration is also closely related to hydrothermal processes. The Southeast area is also in the field supported by many hot springs.

On the $\mathrm{CO}_{2}$ distribution map (Figure 8 right), it was found that 4 areas had a fairly high percentage of $\mathrm{CO}_{2}$. Where the Southeast and East regions have hot water output, then the West area of the lake is an 
area that actively releases gas bubbles, while for the northern area there is no waterlogging, because the area is steep, so that neither hot water nor gas bubbles are found.
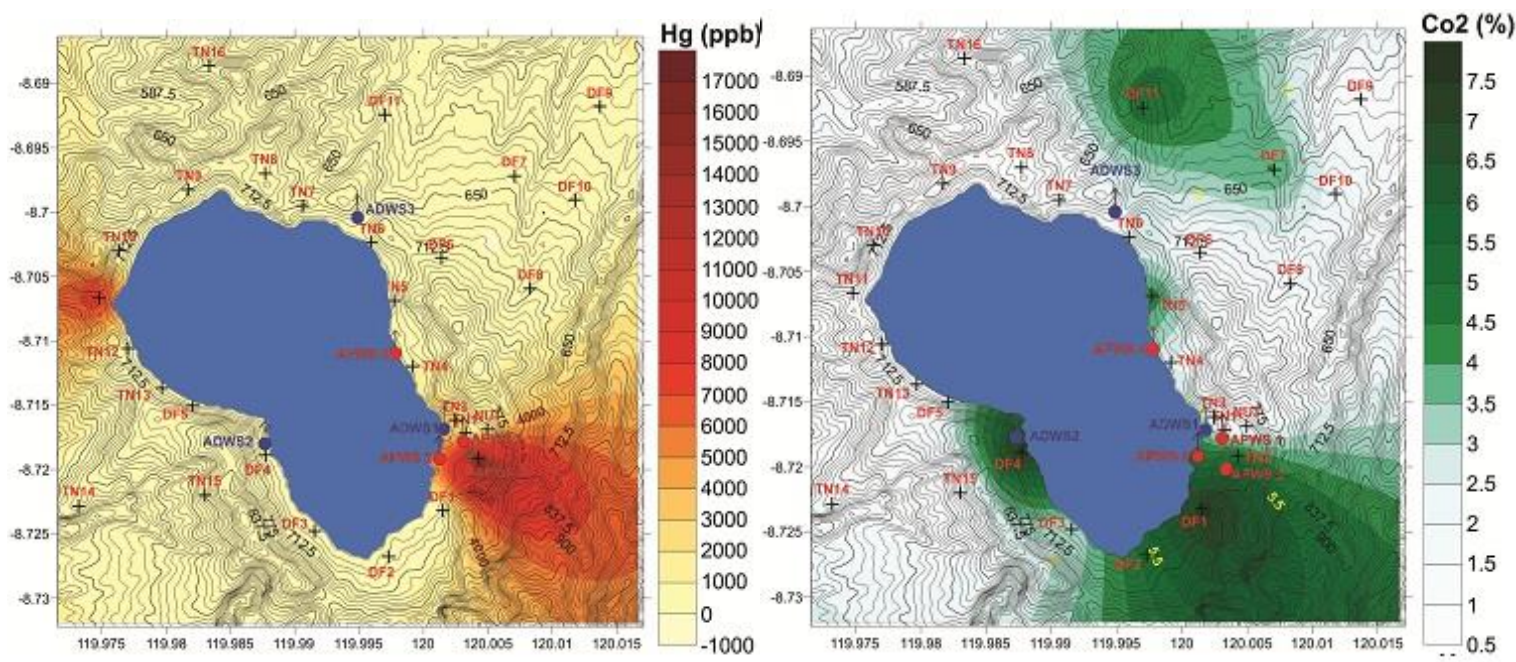

Figure 8. The $\mathrm{Hg}$ content distribution map (left), the $\mathrm{CO}_{2}$ percentage distribution map (right).

\subsection{The geothermal resources calculation}

The calculation of resources is carried out using the heat loss method, where the laws of physics state that $\mathrm{Q}$ out $=\mathrm{Q}$ in, so the calculation of natural heat loss can represent the amount of energy in the reservoir by calculating the amount of mass that comes out of all springs. It is estimated that the amount of speculative geothermal resources in the study area is $1488.6 \mathrm{kWe}$. The results of the calculation of the depth rate against temperature in the isothermal section show that from a temperature of $81{ }^{\circ} \mathrm{C}$ to $230{ }^{\circ} \mathrm{C}$ a depth distance of $\pm 1456 \mathrm{~m}$ is required so that the rate of the temperature per depth is $97.07 \mathrm{~m}$ $110^{\circ} \mathrm{C}$

\section{Conclusion}

A conceptual model is made as to the conclusion. Conceptual models are made based on the interpretation of remote sensing data, the interpretation of geological data, the interpretation of reservoir conditions based on the results of water geochemical analysis, data from previous researchers, and also supported by the results of soil geochemical analysis.

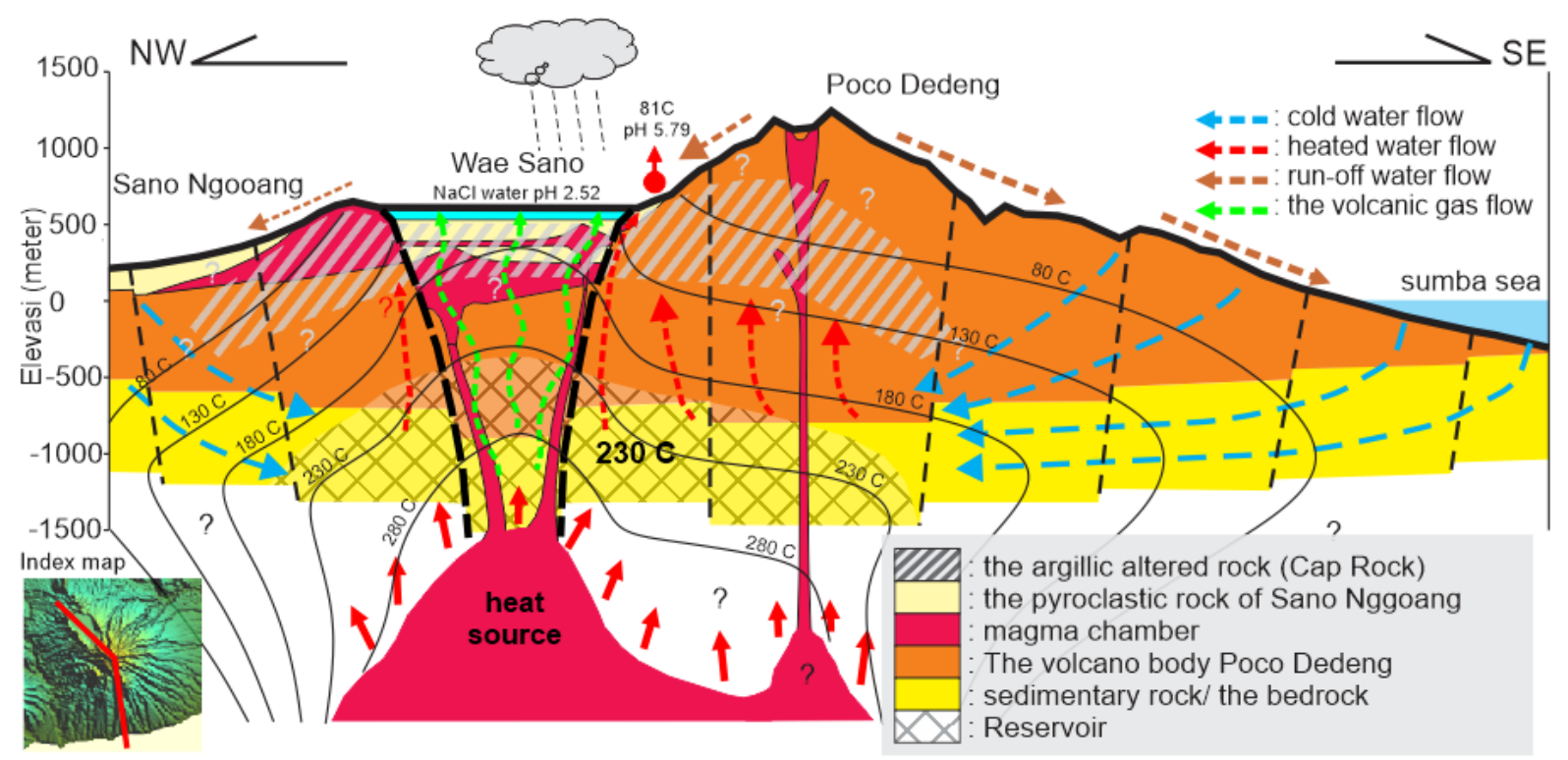




\section{References:}

[1] R. W. Van Bemmelen, "The Geology of Indonesia. General Geology of Indonesia and Adjacent Archipelagoes," Government Printing Office, The Hague. 1949, doi: 10.1109/VR.2018.8447558.

[2] R. Soeria-Atmadja, R. C. Maury, H. Bellon, H. Pringgoprawiro, M. Polve, and B. Priadi, "Tertiary magmatic belts in Java," J. Southeast Asian Earth Sci., 1994, doi: 10.1016/07439547(94)90062-0.

[3] M. Neumann Van Padang, "History of the volcanology in the former Netherlands East Indies.," Scr. Geol., 1983.

[4] . O., D. A. Ramadhan P, F. R. W, and R. T. A, "Identification of Geothermal Potential Based on Fault Fracture Density (FFD), Geological Mapping and Geochemical Analysis, Case Study: Bantarkawung, Brebes, Central Java," KnE Energy, 2015, doi: 10.18502/ken.v2i2.369.

[5] S. Bronto, "Fasies gunung api dan aplikasinya," Indones. J. Geosci., 2006, doi: 10.17014/ijog.vollno2.20061.

[6] S. Bronto, Geologi Gunung Api Purba. 2013.

[7] W. F. Giggenbach, "Geothermal solute equilibria. Derivation of Na-K-Mg-Ca geoindicators," Geochim. Cosmochim. Acta, 1988, doi: 10.1016/0016-7037(88)90143-3.

[8] A. J. Ellis and W. A. J. Mahon, "Chemistry and geothermal systems.," 1977, doi: 10.1016/0031-9201(80)90118-1.

[9] A. J. Ellis and W. A. J. Mahon, "Natural hydrothermal systems and experimental hotwater/rock interactions," Geochim. Cosmochim. Acta, 1964, doi: 10.1016/00167037(64)90132-2.

[10] K. Nicholson, Geothermal Fluids. 1993.

[11] B. Brahmantyo and Bandono, "Klasifikasi Bentuk Muka Bumi untuk Pemetaan Geomorfologi pada Skala 1:25.000 dan Aplikasinya untuk Penataan Ruang," Geoaplika, 2006.

[12] M. N. Hadi, D. Kusnadi, and R. Simarmata, "SURVEI GEOLOGI DAN GEOKIMIA PANAS BUMI DAERAH WAESANO, KABUPATEN MANGGARAI BARAT, PROVINSI NUSA TENGGARA TIMUR," 2015.

[13] M. J. Le Bas and A. L. Streckeisen, "The IUGS systematics of igneous rocks," J. Geol. Soc. London., 1991, doi: 10.1144/gsjgs.148.5.0825.

[14] F. R. Widiatmoko, A. Zamroni, M. A. Siamashari, and A. N. Maulina, "REKAMAN STASIUN GPS SEBAGAI PENDETEKSI PERGERAKAN TEKTONIK, STUDI KASUS: BENCANA TSUNAMI ACEH 26 DESEMBER 2004," in Prosiding Seminar Teknologi Kebumian dan Kelautan, 2019, vol. 1, no. 1, pp. 236-240, [Online]. Available: https://ejurnal.itats.ac.id/semitan/article/view/856.

[15] A. Zamroni, O. Sugarbo, R. Prastowo, F. R. Widiatmoko, Y. Safii, and R. A. E. Wijaya, "The relationship between Indonesian coal qualities and their geologic histories," 2020, doi: 10.1063/5.0006836.

[16] F. R. Widiatmoko, "Pendekatan Analisa Geokimia dengan Multivariate Analysis untuk Mengetahui Tipe Mata Air Panas: Studi Kasus Lapangan Panas Bumi Mapos, Nusa Tenggara Timur,” J. IPTEK, 2019, doi: 10.31284/j.iptek.2019.v23i2.518.

[17] W. F. Giggenbach, "Isotopic shifts in waters from geothermal and volcanic systems along convergent plate boundaries and their origin," Earth Planet. Sci. Lett., 1992, doi: 10.1016/0012-821X(92)90127-H.

[18] A. M. Piper, "A graphic procedure in the geochemical interpretation of water-analyses," Eos, Trans. Am. Geophys. Union, 1944, doi: 10.1029/TR025i006p00914.

[19] G. Ferguson and T. Gleeson, "Vulnerability of coastal aquifers to groundwater use and climate change," Nature Climate Change. 2012, doi: 10.1038/nclimate1413.

[20] M. P. Hochstein and S. Sudarman, "History of geothermal exploration in Indonesia from 1970 to 2000," Geothermics, 2008, doi: 10.1016/j.geothermics.2008.01.001.

[21] R. R. Loucks, "Precise geothermometry on fluid inclusion populations that trapped mixtures of immiscible fluids," Am. J. Sci., 2000, doi: 10.2475/ajs.300.1.23. 